\title{
Epistemological Obstacles to the Analysis of Structures: Giovanni Bottari's Aversion to a Mathematical Assessment of Saint-Peter's Dome (1743)
}

\author{
Pascal Dubourg Glatigny
}

Visible faults in the dome of Saint Peter's basilica in Rome had raised fears about the structure's stability ever since its completion in 1593. The most extensively documented episode of this long history erupted in the early 1740s, a few years after Prospero Lambertini was elected Pope Benedict XIV. The debates over the causes of the cracks, the ensuing scientific analyses, and the adopted solutions are well known, due to the Memorie istoriche della gran cupola del Tempio vaticano, the magisterial treatise published in 1748 by Giovanni Poleni (1685-1761), the mathematician entrusted with the supervision of the restoration work. ${ }^{1}$ One of the great points of interest of this episode was the involvement of competing protagonists and factions, including architects, master carpenters, and natural philosophers. Each of these groups benefited from varying degrees of credibility. Beyond the technical issues concerning the dome's structure, the debate raised important questions about the social and intellectual legitimacy conferred by different forms of expertise.

Church officials also took part, both as consultants to and members of the Reverenda Fabbrica di San Pietro, the administrative body in charge of building, decorating, and maintaining the holy temple. ${ }^{2}$ Among this group was Giovanni Bottari (1689-1775), one of the few figures involved in the discussions who was neither a scientist nor a builder or architect. Although he had no official position in the curia, Bottari was an influential figure of the Roman intellectual scene. ${ }^{3}$ A manof-letters and connoisseur, Bottari took part in the controversy from its earliest days as a member of the congresso, the special commission convened by the pope to explore the problem in January 1743. In his Memorie istoriche, Poleni mentions Bottari's name infrequently and only incidentally, reporting neither his statements nor his position. Bottari, however, claimed to speak with the voice of public opinion

\footnotetext{
P. Dubourg Glatigny ( $₫)$

Centre Alexandre Koyré, 27 Rue Damesme, 75013 Paris, France

e-mail: pascal.dubourg@cnrs.fr
} 
(la voce commune), and he was the only participant who publicly opposed any form of restoration. Indeed, he regarded the building improvement as unnecessary and extremely risky.

A series of official documents and private letters, preserved in Venice, Rome, and the Vatican, provides evidence of the peculiar outsider's role that Monsignor Bottari played in this story. He greatly distrusted both architects and mathematicians, regarding both groups as opportunists. According to him, the architects were motivated primarily by the prospect of gaining new work-indeed, a prominent commission in the most important church of the Christendom-while the scientists seemed eager to grasp any opportunity to strengthen their influence on society. Paradoxically, it was the mathematicians to whom Bottari objected most vigorously. Their approach served to reduce the Vatican Temple to a mere mathematical object, denying its historical, spiritual, and aesthetic significance.

\section{The Parere di tre mattematici: The Building as a Mathematical Object}

The controversy developed very quickly toward the end of summer 1742, when rumors about a possible collapse of the dome first began circulating. In October, the papal physician (archiatra pontificio) Antonio Leprotti wrote to his friend Bottari to learn more about the worrying gossip (le strepitose ciarle) spreading through town. ${ }^{4}$ The chatter must have been widespread and at least partly credible. On 21 November 1742 , following a site visit in late September, the Pope decided to commission an expertise by "the most eminent mathematicians," fathers François Jacquier (17111788) and Thomas Le Seur (1703-1770) of the Minim order. The Jesuit Roger Boscovich (1711-1787) joined the two monks soon after. The French mathematicians had a peculiar position in the Roman scientific landscape. As editors of the most recent edition of the Principia, published in Geneva, they were well-known Newtonians. ${ }^{5}$

This "external" consultation was supposed to put an end to growing uncertainty, the result of several inconclusive investigations conducted over the years by the Fabbrica's own architects. The papal commission strived to be clear therefore about the subject, scope, and limits of the review, which was intended to be definitive. The document underlines the need to establish an opinion "not so much on the present state of the damage observed on the dome, but rather on its restoration, so that the architects can implement the solutions considered to be the most necessary." ${ }^{\prime \prime}$ Faced with a great diversity of opinion among the architects and the master builders, the Fabbrica called on the mathematicians with the hope of settling the argument.

To publicize its results, the commission published an official report in early 1743. The Parere di tre mattematici is a short booklet organized into three parts. ${ }^{7}$ After a brief description of the dome, the first part presents the damage observed by the mathematicians themselves. It lists meticulously the various cracks and attempts to establish, as far as possible, when they appeared by comparing "the present state 
of the dome with an earlier one." The latter effort was only partially successful, due to the lack of archival evidence. The second part tries to determine if the cracks were due to a structural instability or to accidental causes, such as wind loading or ground settlement. The last part is dedicated to the presentation of the "system", a theoretical model of the structure used to elaborate the proposed solution. The authors carefully correlate the system to the present state of the building and calculate the interaction of weights and forces occurring within it. In conclusion, they recommended the placement of iron rings around the dome and the buttresses of the drum. Despite the scientific analysis and extensive calculations, the solution was traditional. Iron chains and rings were used widely to ensure the stability of domes. In fact, two such devices had already been incorporated into the dome of St Peter's during its construction.

The explanation of the "general system" is accompanied by certain hypotheses, with the restrictions Newton gave to this word. ${ }^{8}$ They serve to determine the centre of gravity and its practical consequences, as well as the method of calculating the thickness of the pillars. Architects were used to treating these issues with practical rules-of-thumb, but here they are treated in a novel way. The system conceives the dome as an organic complex of abstract elements, while eliminating indeterminate causes, that is, factors that cannot be calculated. Such unknowns might include the state of the foundations, the firmness of the ground, or the effects of natural phenomena, including wind, lightning, or earthquakes. To elaborate a solution grounded on reason, the mathematicians try to isolate their object, as a natural philosopher working in his cabinet would isolate a phenomenon in an experiment. In this connection, their use of Musschenbroek's conclusions on the resistance of materials is particularly relevant. ${ }^{9}$ Excerpting his value for the resistance of iron, they applied it directly to the existing iron ring around the dome. Possible variables, however, that might influence this force-the regularity of the ring's dimensions, the quality of the screws fixing the different elements together, or its present state of conservation-are not considered. In this analysis, the dome is transformed into an object of purely theoretical knowledge. Indeed, most of the authors' supporting references are to recent work by the French Academy of Sciences, in particular to the essays of Philippe de La Hire. ${ }^{10}$ The publication's sole engraving illustrates the damaged cupola in elevation and section, juxtaposed with force diagrams of the different theories discussed in the text (Fig. 1). Architects were no strangers to problems of stability, but the authors were clear that their approach would be different. In the preamble to their study, the mathematicians affirmed that this "special situation is one that requires the theories of mathematicians more than practice."11 Architects' expertise, in particular, was implicitly excluded from the demonstration.

The mathematicians' conclusions were printed in early January 1743 and distributed widely among scholars and amateurs. On 22 January, the Pope convened a congress at the Quirinal to agree on a definitive solution. During this meeting, Boscovich demonstrated the system, showing the audience the network of cracks then visible. For this, he used the model of the dome constructed by Michelangelo between 1558 and 1561, on which Luigi Vanvitelli (1700-1773), official architect of the Fabbrica, had drawn the positions and shapes of the faults (Figs. 2 and 3). 


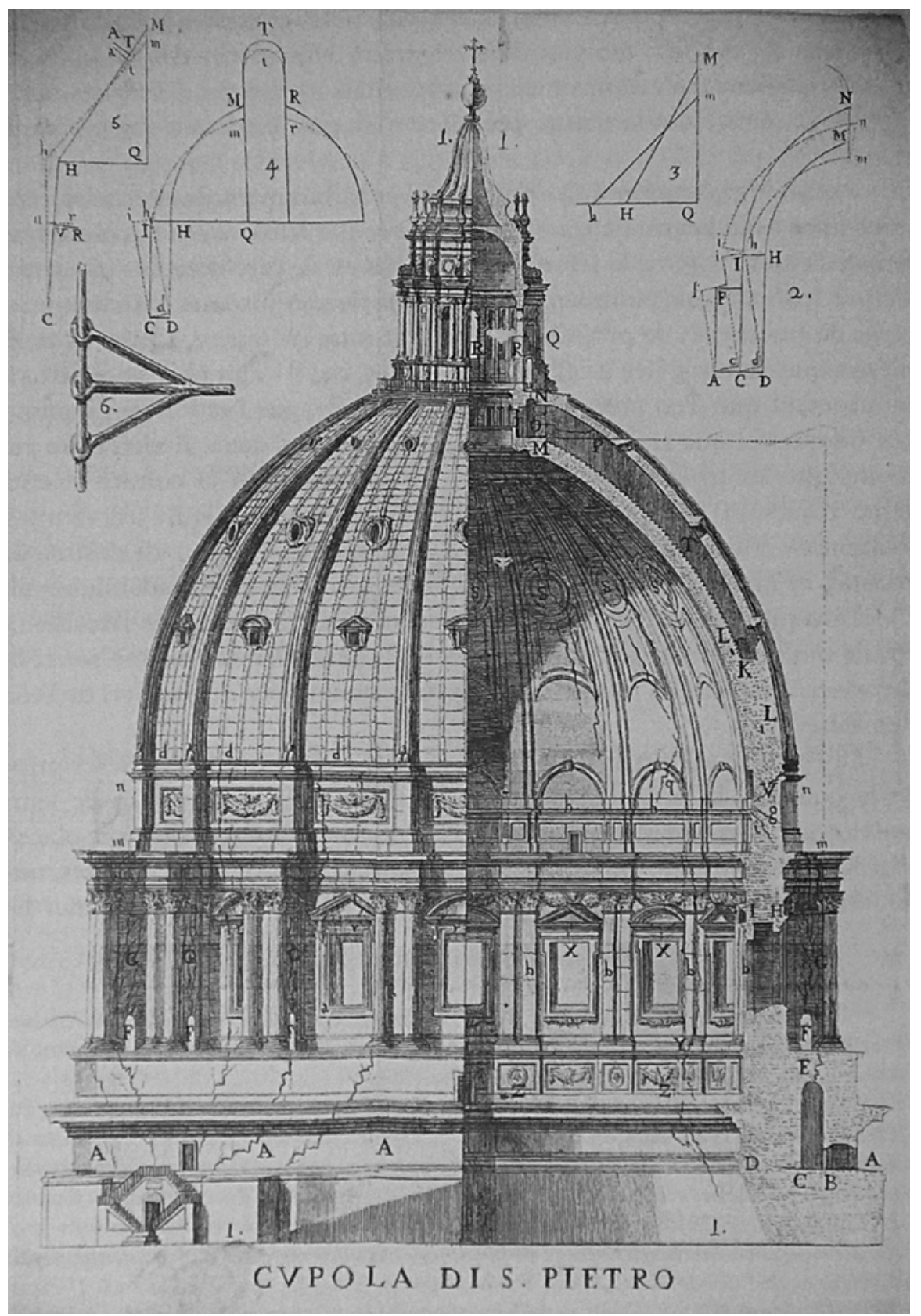

Fig. 1 Elevation and section of the damaged cupola of St Peter's, juxtaposed with force diagrams (From Jacquier et al. [1742]) 


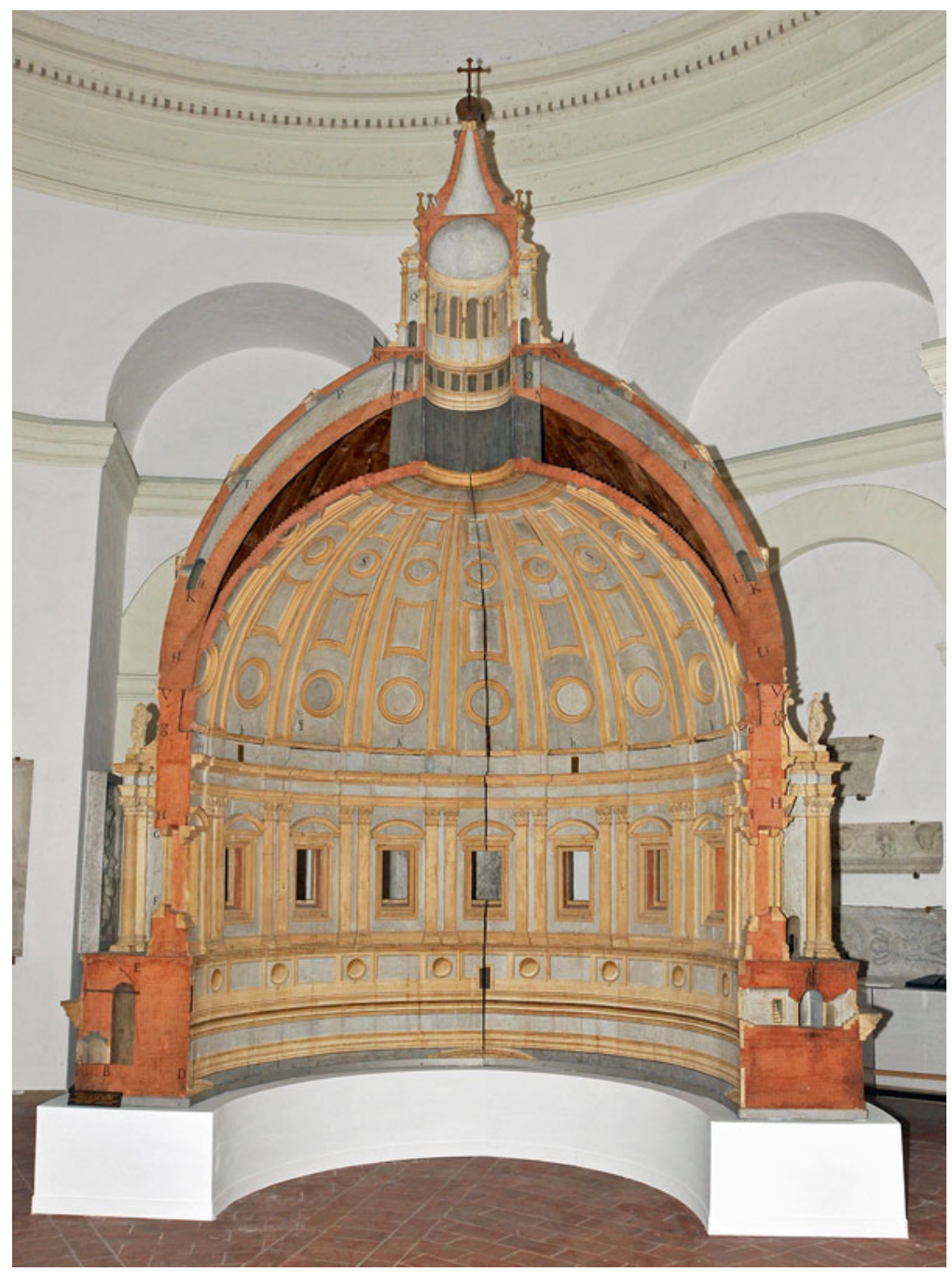

Fig. 2 Wooden model of Michelangelo's dome of St Peter's basilica, 1558-61, with later additions by Giacomo della Porta

The audience was selected by the administrator of the Fabbrica, Francesco Olivieri. ${ }^{12}$ The participants were composed of three different groups. First were the architects and builders from inside and outside the Fabbrica, including Luigi Vanvitelli, Ferdinando Fuga (1699-1782), and Nicola Salvi (1697-1751). The second group consisted of other mathematicians like our three authors. They included Diego Revillas (1690-1746) and Michelangelo Giacomelli (1695-1774). There were, finally, two amateur non-specialists, the marquis Girolamo Theodoli (1677-1766) and Giovanni Bottari. Curiously, other than Olivieri, none of the cardinals of the 


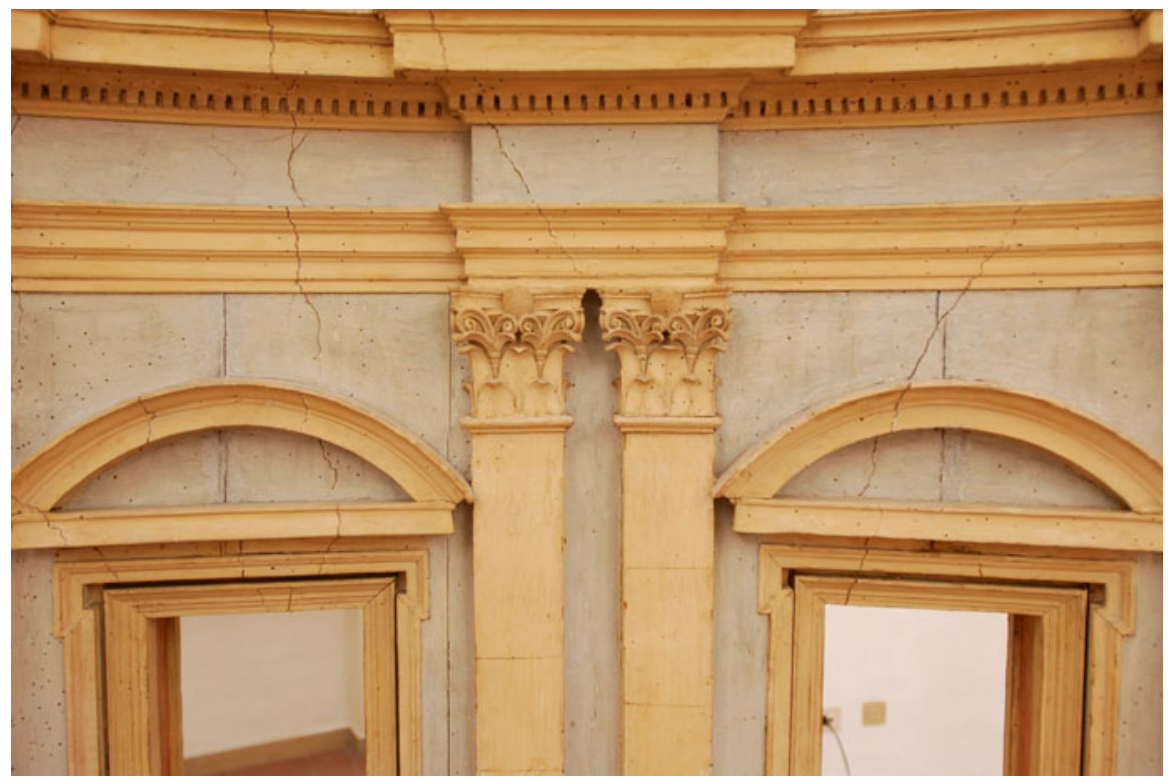

Fig. 3 Detail of the wooden model of Michelangelo's dome, showing painted "cracks" in the structure by Luigi Vanvitelli

Fabbrica was present. This was contrary to the normal custom of the institution, which required any work in or on the Basilica to be approved by a committee of its members.

"Everyone acknowledges the damage" was the official conclusion of the congress. The few expressed reservations were mostly trivial. Revillas, for one, doubted whether the cracks in the crossing piers were related to those observed in the dome. The former had given rise to a controversy in 1680 over Bernini's intervention in the crossing. ${ }^{13}$ Likewise, concerning the prescribed solution, all architects agreed with the three mathematicians: that new rings should be installed. Among the architects, only Filippo Barigioni claimed to have difficulties with the proposed solution, but only "from the attic and above." His reservations appear to contest the placement of rings, rather than the solution itself. The relative unanimity among the participants, however, was more apparent than real. Bottari was the sole member of the commission to take the unusual step of withholding his opinion. He announced that he would offer one only after a site visit and would let it be known in written form.

\section{Giovanni Bottari and the Nature of Architecture}

How and why Bottari was included in the commission is hard to establish. Bottari was a scholar from Florence, famous for his work on grammar and literature. Also trained in geometry, he had edited an edition of Galileo's works, as well as a 
compendium of Apollonius' Conics by the Pisan professor Guido Grandi. ${ }^{14}$ Close to Bartolomeo Corsini, nephew of then-pope Clement XII, Bottari followed his patron to Rome in 1730. In the early 1730s, he was asked to consult on several hydraulic projects, particularly in the river Po area. It was during this period that Bottari may have met the Bolognese mathematician Eustachio Manfredi, who would also later be involved in the dome controversy. In 1732, Bottari accompanied Manfredi to the Tiber in Perugia to examine the possibility of making a portion of the river navigable. ${ }^{15}$ This experience may have given Bottari some legitimacy in the fields of engineering and architecture. The election of Benedict XIV furthered Bottari's opportunities for patronage. He was nominated to several academies, in particular, that of Saint Luke, becoming an "academician of honour" in $1738 .{ }^{16}$

Bottari had a polemical mind, involving himself continuously in cultural, doctrinal, and theological controversies. He had a great interest in the arts, Tuscan artists, in particular; his name is still famous for his edited collections of artists' letters and unpublished documents. ${ }^{17}$ His own views on art were transmitted mainly through the Dialoghi sopra le tre arti del disegno published in 1754, in which he proposed a fictitious dialogue between the biographer Giovanni Pietro Bellori and the painter Carlo Maratta. Bottari apparently started it when he arrived in Rome in the 1730s, intending to defend the prestige of Tuscan artistic values in the Holy City. A hypercritical book, first published anonymously, it is tinged with a strong feeling of campanilismo and disparages many contemporary Roman painters. It also remains a cornerstone of the historiography of painting conservation. ${ }^{18}$ More important for our purpose, however, is the large part of the second dialogue dedicated to architecture, specifically to the question of domes and vaults. It is here that Bottari makes precise reference to Saint Peter's dome.

The discussion concerns Michelangelo's intervention in the design following the death of Antonio Sangallo the Younger and focuses, in particular, on the sculptor's battles with the "Sangallo sect", who accused him of having ruined the building. To this charge-evidently still a live issue in the early eighteenth century-Bottari countered vigorously: "Michelangelo surpassed all the Greeks and made something look rather like a divine miracle than any human artifact." ${ }^{19}$ In the mouth of Maratta, Bottari later qualifies the dome as "an admirable machine whose excellence is quite obvious to anybody." ${ }^{20}$ This conception of the dome contrasts emphatically with that of the three mathematicians. Bottari saw the work primarily as the product of human art and ingenuity and as the legacy of a "divine"—not to mention Tuscan-artist. It was the pre-eminent building of the modern age, surpassing not only the architecture of contemporaries like Sangallo but that of the ancients themselves. Bottari's humanist notion of excellence as a criterion of quality in the arts extends even to its structural character. The dome is emphatically not a sistema, but a macchina-in the ancient sense of a structure excelling by its size and stability.

Bottari's defense of Michelangelo also reveals a general suspicion of the professional ambition of Roman architects, an admonition he would later make repeatedly in his assessment of the various proposals to restore the dome. In the Dialoghi, this sentiment is particularly apparent in his criticism of Luigi Vanvitelli, whom the author chastised for having spoiled Michelangelo's work at Santa Maria degli Angeli. 
To Bottari, Vanvitelli's work manifested nothing less than "the depravity in which this century has fallen in architecture." ${ }^{21}$ Vanvitelli was, of course, the acting architect of the Fabbrica of Saint Peter's, responsible for the restoration work on the dome in the 1740s.

Bottari's position here must not be misunderstood. In no sense was he rejecting the role of mathematics in architecture. In the Dialoghi themselves, he emphasized the necessity of "universal rules... to teach how to calculate the strength of the arches and of the vaults, the resistance of the wall structure, how to balance the forces, which can be only learned from geometrical doctrine, mechanics, and similar learning." ${ }^{22}$ Nor did Bottari have difficulty with mathematicians. He was particularly friendly with Poleni, with whom he corresponded both before the controversy broke out and after. ${ }^{23}$ Bottari's position, rather, is that mathematics-indeed, science in general-must be absorbed by ingegnium. This intellectual capacity is not only linked with grace and beauty, it also relies on historical knowledge. In the same way that an architect chooses a particular element according to a detailed knowledge of its historical use and from the analysis of a particular situation, a suitable mathematical analysis must respond to the history and use of its object. Indeed, this was a case where the analysis had to be particularly sensitive, given the building's symbolic importance and institutional context.

After the meeting of 22 January 1743, Bottari reserved the right to express his views in a written statement. His declaration is known to us through a manuscript copy kept in the Vatican library. ${ }^{24}$ In this document, he first described the Parere of the three mathematicians. He characterized it as consisting not of three parts, but of four: "two of facts and two of speculation, the last two based on the foundations of the first." Where the authors had described the visible damage to the dome in one section, Bottari was careful to distinguish the more recent cracks from the older, historically verified ones. He insisted that "the system of damages" suggested in the last part constituted a construction logically based on the facts established in the first. His main criticism was that this part of the work was imprecise and incomplete, rendering the conclusions false. The description of the cracks had not been elucidated in enough detail, nor did it provide a comprehensive picture of the situation. Furthermore, the vocabulary used by the three mathematicians was vague and unspecific. Bottari acknowledged that the mathematician's statement had been carefully established after many visits on the scene, but he still considered the results far from satisfying. The investigators, he pointed out, had measured only the length of the cracks, not their width or depth. Some facts, moreover, had been taken from another report, without verifying them or quoting the source. The authors had relied on this account for the measured incline of the leaning walls and piers of the drum. "Blind belief is the enemy of geometry," wrote Bottari, castigating the authors for failing to make their own direct visual investigation. A particularly important indicator was the dovetailed marble revetments (marmi a coda di rondine) placed in different places on the most visible cracks. These had been recently installed only to be broken by continued movement of the structure and therefore constituted one of the mathematicians' main arguments for an urgent intervention. Bottari, however, considered it impossible to deduce anything from their assertions. The authors had 
failed to report the dates when the marble plates were fitted, nor the exact variation between broken and unbroken pieces, or the number of the plates involved.

Bottari's Jansenist sympathies may have prejudiced him against the three mathematicians - members of both the Minims and the Jesuits-but religious differences are not sufficient to explain his position. Nor was it simply a question of method and insufficient precision. His reticence was also linked to the idea of the "system" and to a lack of diachronic and historical perspective in the analysis of the building. He recognized the system as an ingenuous proposition, but was very severe on its content. The principal difficulty was the lack of firm historical data about the state of the dome in the seventeenth century. Earlier site reports, for instance, those made by Mattia dei Rossi or others from 1680, were insufficiently precise to allow any conclusions to be drawn about subsequent deterioration. Nor did the commission's apparent unanimity deter him. As the three authors had themselves admitted, the solutions proposed were traditional: "more from architects than from geometers." As Bottari suggested in his discourse about the restoration of the works of art, architects and artists remain on the side of the project, while scholars control the reception and the a posteriori judgment. This demarcation was to be even more carefully observed in such a highly symbolic historic monument. The judgment of the committee's technical experts therefore meant little to him.

The mathematicians realized immediately that they faced a dangerous enemy. They even had to apologize to the physician Leprotti, promising him that they would do nothing to offend Bottari. ${ }^{25}$ He made the mathematicians all the more defensive by spreading rumors that their calculations were false. As Boscovich complained to Poleni three days after the meeting, "a voice is increasing in Rome that all of our calculations are wrong, that everything relies on false suppositions." ${ }^{26}$ Boscovich hoped to gain Poleni's support as an undisputed authority, far from the curia with its scheming and back-stabbing. He defended his work in a series of letters: "We have made the calculations several times," he wrote just after the congress, "and verified the data by numerous measures because we found many inaccuracies in the previous drawings." Boscovich also defended the principles followed in the redaction of the booklet, saying "we could only allude to the more difficult things and had to summarize even the most elementary ones in order to be understood in a country where very few people are acquainted with geometry and even fewer with calculation." ${ }^{27}$ Such an excuse would hardly have satisfied his Roman audience.

Bottari was the only participant of the congress to reject the presentation of the three mathematicians in its entirety. This refusal was aimed not only at their intellectual background, their "Newtonianism". Bottari's criticism on the quality and reliability of their inquiry disguised a deeper opposition. That is to say, he used their own tools and arguments to contest their entire approach to the question. As we have seen in the Dialoghi and in his statement following the congress, Bottari preferred to qualify the dome with the word "machine". He understood this term in its Renaissance sense as a complex of material elements connected one with the other in order to serve a specific function, whether structural, productive, or demonstrative. ${ }^{28}$ This "machine", moreover, had a history. The design and construction of the dome belonged to a long tradition of handicraft and erudition brought to a 
culmination by Michelangelo. A product of his ingegnium, it surpassed the works of both the Greeks and the moderns, to become something like a "divine, almighty miracle." The word machine subsumes all of these meanings. "System", on the other hand, is the word the three mathematicians endorse. They use "system" both for the dome and equally for the analysis of its present state. A system is a complex of abstract elements, not necessarily linked to a material structure. A system can be studied independently from its context, its historicity, its function.

In the end, Bottari was not able to prevent the Fabbrica from engaging restoration work. The dome, it was believed, could collapse at anytime. This fear was not ungrounded; some of the cracks were wide enough to step through. Nor was Bottari able to impose an alternative solution to the abhorred metal rings. Although he claimed Michelangelo rejected their use, he was perfectly aware that a couple of rings had already been incorporated into the structure. Bottari, however, did achieve two of his goals. The first was to exclude the three mathematicians from the supervision of the restoration work; they were soon replaced by Giovanni Poleni. The second was to compel Poleni and the Fabbrica to gather a special team of collaborators, responsible for compiling documentation about the dome for the official history, published in 1748. The enormous amount of technical and historical material that they gathered became the basis of Poleni's Memorie istoriche della gran cupola, still the major source for this controversy. Although Poleni's analysis-and proposed solution-were similar to those of the three mathematicians, he presented them in a way that did not neglect, but rather complemented the demonstrative historical method that Bottari advocated. Poleni, too, recognized the very peculiar character of the "Vatican Temple"-in both its symbolic role and as the product of a very protracted and unusual decision-making process - and adapted his analysis to it. Subsequent studies have downplayed the broader scholarly context of Poleni's mathematical analysis, but it was integral to the conception of the treatise and points to a hitherto unknown aspect of its background and origin.

\section{Notes}

1. Poleni (1748).

2. On the Reverenda Fabbrica di San Pietro, see Marconi (2004, 19-36); Basso (1987) and Sabene (2012).

3. The bibliography on Bottari is very scarce. No monograph has yet been dedicated to this important figure of the roman Settecento. In the meantime, see Pignatelli and Petrucci (1971) and Consoli (2004, 143-50).

4. Letter from Leprotti to Bottari (20/10/1742), Carteggio Bottari 1660 (32E21), Biblioteca Corsiniana, Rome, fol. 62r-63r.

5. Newton (1739-1742).

6. Arm. 50, B, 17, Archivio della Reverenda Fabbrica di San Pietro (ARFSP), Vatican City, fol 997r. 
7. Jacquier, Leseur, and Boscovich (1742). This study has been presented and discussed elsewhere. See, most recently and with references to earlier work: Dubourg Glatigny and Le Blanc (2005), 189-218.

8. Chaudhury (1962).

9. Jacquier, Le Seur, and Boscovich (1742, 27-28).

10. See, in particular, de La Hire $(1695,1712)$. Also see Couplet $(1712,1730)$.

11. Jacquier, Le Seur, and Boscovich $(1742,4)$.

12. The manuscript of Olivieri's notification to participants is kept in Cicognara V-3849, int. 2, \#1, Biblioteca Apostolica Vaticana. The list of invited speakers is in Arm. 50, B, 17, ARFSP, fol. 998r.

13. On this episode, see Dubourg Glatigny (2009) and Marder (2008).

14. See Galileo (1718) and Apollonius (1722).

15. Bottari's account was later published in Gambarini (1746).

16. Libro dei decreti dell'insigne Accademia di S. Luca dalli 22 luglio 1726 a li 12 Maggio 1738 (vol. 49), Archive of the Accademia di San Luca, Rome, fol. 183 v.

17. Bottari (1754-1773).

18. See also Bottari's important re-edition, in 1730, of Raffaello Borghini's Il Riposo. On this work, see Procacci (1955, 229-49).

19. Bottari $(1865,31)$.

20. Bottari $(1865,60)$.

21. Bottari $(1865,35)$.

22. Bottari (1865, 84-85).

23. Bottari wrote to Polieni about Vitruvius in 1741 and kept him posted on the dome controversy, at least until 1744. Several letters from Poleni to Bottari are kept in Carteggio Bottari, 32G33, Biblioteca Corsiniana, Rome, fol. 4r, 8r, 10r, 24r.

24. Cicognara V-3849, int. 2, \#3, Biblioteca Apostolica Vaticana.

25. Carteggio Bottari, 1660 (32E21), Biblioteca Corsiniana, Rome, fol. 66r.

26. Boscovich to Poleni, 25 January 1743, Mss. Italiani, cl. 10, $\mathrm{n}^{\circ} 304$ (6544), Biblioteca Marciana, Venice.

27. Boscovich to Poleni, 22 January 1743, Mss. Italiani, cl. 10, n 304 (6544), Biblioteca Marciana, Venice.

28. Popplow (2007).

\section{Photographic Credits}

Private collection: Fig. 1

Fabbrica di S. Pietro in Vaticano: Figs. 2, 3

\section{References}

Apollonius. 1722. Compendio delle sezioni coniche. Florence: Tartini e Franchi.

Basso, Michele. 1987. I privilegi e le consuetudini della Rev.da Fabbrica di San Pietro in Vaticano (sec. XVI-XX). Rome: Typis polyglottis vaticanis. 
Borghini, Raffaello. 1730. Il riposo, ed. Antonio Maria Biscioni and Giovanni Gaetano Bottari. Florence: M. Nestenus, F. Moücke.

Bottari, Giovanni Gaetano. 1754. Dialoghi sopra le tre arti del disegno. Lucca: F.M. Benedini.

Bottari, Giovanni Gaetano. 1754-1773. Raccolta di lettere sulla pittura, scultura ed architettura. Rome: Niccolò e Marco Pagliarini.

Bottari, Giovanni Gaetano. 1865. Dialoghi sopra le tre arti del disegno. Parma: Pietro Fiaccadori.

Chaudhury, Pravas Jivan. 1962. Newton and hypothesis. Philosophy and Phenomenological Research 22(3): 344-353.

Consoli, Gian Paolo. 2004. Giovanni Gaetano Bottari e Francesco Algarotti: per una genealogia del neoclassicismo. In Ferdinando Sanfelice: Napoli e l'Europa, ed. Alfonso Gambardella, 143-150. Naples: Edizioni Scientifiche italiane.

Couplet, Pierre. 1712. De la poussée des voûtes. Histoire de l'Académie royal des sciences, avec les mémoires de mathématique et de physique: Part II, Mémoires, 79-117. Paris: Imprimérie royale, 1729.

Couplet, Pierre. 1730. Seconde partie de l'examen des voûtes. Histoire de l'Académie royal des sciences, avec les mémoires de mathématique et de physique: Part II, Mémoires, 117-141. Paris: Imprimérie royale, 1730.

de La Hire, Philippe. 1695. Traité de mechanique. Paris: Jean Anisson.

de La Hire, Philippe. 1712. Sur la construction des voûtes dans les edifices. Histoire de l'Académie royal des sciences, avec les mémoires de mathématique et de physique: Part II, Mémoires, 69-77. Paris: Imprimerie royale, 1731.

Dubourg Glatigny, Pascal. 2009. Bernin disputé: science, art et architecture dans la Rome de 1680. In Conflicting duties: Science, medicine and religion in Rome, 1550-1750, ed. Maria Pia Donato and Jill Kraye, 89-108. London: Warburg Institute.

Dubourg Glatigny, Pascal, and Marianne Le Blanc. 2005. Architecture et expertise mathématique: La contribution des Minimes Jacquier et Le Seur aux polémiques de 1742 sur la coupole de Saint-Pierre de Rome. Mélanges de l'Ecole française de Rome, Italie et Méditerranée 117(1): 189-218.

Galilei, Galileo. 1718. Opere di Galileo Galilei Nobile Fiorentino, ed. Tommaso Buonaventuri, Guido Grandi, and Benedetto Bresciani. Florence: Gio. Gaetano Tartini e Santi Franchi.

Gambarini, B. 1746. Delle ragioni, e de'rimedi delle inondazioni del Tevere, della somma difficoltà d'introdurre una felice e stabile navigazione da Ponte Nuovo sotto Perugia, fino alla foce della Nera nel Tevere e del modo di renderlo navigabile dentro Roma. Rome: Antonio de'Rossi.

Jacquier, François, Thomas Leseur, and Ruggero Giuseppe Boscovich. [1742]. Parere di tre mattematici sopra i danni, che si sono trovati nella cupola di S. Pietro sul fine dell'anno [1742] dato per ordine di Nostro Signore Papa Benedetto XIV.

Marconi, Nicoletta. 2004. Edificando Roma Barocca. Rome: Edimond.

Marder, Tod A. 2008. A finger bath in rosewater: Cracks in Bernini's reputation. In Sankt Peter in Rom 1506-2006, ed. Georg Satzinger and Sebastian Schütze, 427-434. Munich: Hirmmer.

Newton, Isaac. 1739-1742. Philosophiae naturalis principia mathematica. Geneva: Barillot et fils.

Pignatelli, G., and A. Petrucci. 1971. Giovanni Gaetano Bottari. Dizionario Biografico degli Italiani. http://www.treccani.it/biografie.

Poleni, Giovanni. 1748. Memorie istoriche della gran cupola del tempio Vaticano. Padova: Stamperia del Seminario.

Popplow, Marcus. 2007. Setting the world machine in motion: The meaning of the Machina Mundi in the middle ages and the early modern period. In Mechanics and cosmology in the medieval and early modern period, ed. Massimo Bucciantini, Michele Camerota, and Sophie Roux, 45-70. Florence: L.S. Olschki.

Procacci, Ugo. 1955. Di uno scritto di Giovanni Bottari sulla conservazione e il restauro delle opere d'arte. Rivista d'arte 30: 229-249.

Sabene, Renata. 2012. La fabbrica di San Pietro in Vaticano. Rome: Gangemi. 